\title{
NOTE
}

\section{Immunoreactive 7B2 Concentrations in Rats with Various Endocrine Conditions}

\author{
Hitoshi SUZUKI, Yoshinisa HASHIGAMI, Yoshinobu SUZUKI, \\ Hirobumi KOBORI, RyuUsuke OHTAKE, Hiroaki MURAMATSU, \\ ToKiniko TSUCHIYA, TAMIO IEIRI AND SHIN-ICHI SHIMODA
}

\author{
Department of Endocrinology, Internal Medicine, School of Medicine, \\ Dokkyo University, Mibu, Tochigi 321-02, Japan
}

\begin{abstract}
Changes in 7B2 immunoreactivity in the pituitary as well as in the other brain regions and gut after various endocrine situations were investigated. Gonadectomy and neonatal monosodium glutamate (MSG) treatment resulted in an appreciable increase in the pituitary 7B2 concentration, though 7B2 content in the MSG treated pituitary was not significantly different when calculation was performed on a per pituitary gland basis. The 7B2 concentration in the cerebellum, midbrain and cortex in thyroxine treated rats showed a significant increase, which might indicate possible thyroid hormone involvement in 7B2 metabolism in the brain. The pituitary 7B2 concentration during the estrous cycle did not change significantly. These results suggest that pituitary 7B2 may correlate to the pituitary gonadotropins and that brain $7 \mathrm{~B} 2$ content may be modulated by thyroid hormones.
\end{abstract}

The peptide $7 \mathrm{~B} 2$ was first extracted from the porcine and human pituitary glands (Hsi et al., 1982; Seidah et al., 1983). Subsequent studies by radioimmunoassay (RIA) revealed its presence outside the pituitary glands, that is, in the brain (Iguchi et al., 1984, 1985), spinal cord

Received December 9, 1988

Correespondence to: Dr. HiTOSHI SUZUKI, Department of Endocrinology, Internal Medicine, School of Medicine Dokkyo University, Mibu, Tochigi 321-02, Japan

This work was supported in part by a Grant in Aid for Scientific Research from the Ministry of Education of Japan (No. 62770858).
(Suzuki et al., 1985), pancreas (Suzuki et al., 1987), gut, thyroid gland and adrenals (Iguchi et al., 1984). This novel peptide 7B2 was also shown to be released by high potassium stimulation (Iguchi et al., 1984; Deng et al., 1986) or luteinizing hormonereleasing hormone ( $\mathrm{LH}-\mathrm{RH})$ from the pituitary (Deng et al., 1986) and a pheochromocytoma cell line (PC 12) in vitro (Suzuki et al., 1986 a), suggesting that 7B2 may be a peptide secreted by these endocrine glands. Because of the lack of a pure synthetic peptide, the function of this novel peptide has not yet been known.

In this study, we intended to assess 
whether there was any change in the 7B2 concentration in any of the specific conditions mentioned below.

\section{Materials and Methods}

\section{Experimental animals}

All animals used in this study were male and female Wistar-derived rats obtained from a commercial source. They were housed, at least two weeks prior to an experiment, in a room with controlled temperature $\left(25 \pm 1^{\circ} \mathrm{C}\right)$ and lighting (lights on 0800 to $2000 \mathrm{~h}$ ), and given rat food and tap water ad libitum. The rats weighed between 200 and $300 \mathrm{~g}$ when used. Female rast of Sprague-Dawley strain were also employed to study whether any changes occurred in the pituitary or hypothalamic $7 \mathrm{~B} 2$ concentration during the estrous cycle. Following repeated observation of vaginal smears taken early in the morning, rats which showed at least three regular 4-day cycles were selected. In the morning of the experiment, the final smears were taken from the selected rats, and the stages of the estrus cycle were determined (Schwartz \& Bartosik. 1962). Rats which showed typical proestrus $(n=9)$, estrus $(n=18)$, metestrus $(n=8)$ and diestrus $(n=15)$ respectively, were immediately decapitated with a guillotine.

\section{Endocrinological treatments Thyroid dysfunction}

To manipulate the thyroid status and to study 7B2 content, 7 male Wistar rats were injected with $20 \mu \mathrm{g}$ 1-thyroxine (Sigma Co. St. Louis, MO, USA) daily for 2 weeks. Nine rats had been given $0.2 \%$ methyl mercaptoimidazole (MMI ; Sigma Co.) instead of water for 4 weeks. Six rats served as controls and were given food and water ad libitum.

\section{Adrenalectomy}

Twelve male rats were adrenalectomized. The adrenalectomized animals were given $1.0 \%$ saline ad libitum instead of water. All of the operated rats and 7 control rats were killed 2 weeks after the treatment.

\section{Gonadectomy}

Castrated $(n=11)$ and ovariectomized $(n=8)$ Wistar rats and control rats of each sex $(n=7$ of each) were killed 2 weeks after gonadectomy.

\section{Neonatal monosodium l-glutamate (MSG) treatment}

Male and female rats were mated and their offspring received a subcutaneous injection of $4 \mathrm{mg} / \mathrm{g}$ body weight MSG (Wako Chemicals Co., Tokyo, Japan) on alternate days for the first 10 days of life. Control pups received equivolume injections of $10 \%$ saline as an isotonic control. At 21 days of age, the offspring were weaned and placed in group cages according to sex and treatment. In the experiments, only male rats were used when they reached approximately 15 weeks of age.

\section{Sample preparation}

The animals were decapitated with a guillotine with a minimum of handling. The trunk blood was collected into tubes containing $1 \mathrm{mg}$ of ethylenediamine tetraacetate (EDTA; Wako Chemicals) and 400 K.I.U. of aprotinin (Sigma Co.) per $\mathrm{ml}$ of blood. Pituitary glands were rapidly removed. The hypothalamus and some other brain regions (brainstem, midbrain, cerebellum, thalamus, striatum and cortex) were dissected according to methods described previously (Glowinski \& Iversen. 1966; Heffner et al., 1980). The pancreas and gastrointestinal (GI) tract (stomach, duodemum, ileum and colon) were also dissected so as to be as free as possible from fatty tissue. Each tissue sample was weighed and immersed in $1 \mathrm{ml}$ of boiling 0.5 mole/L acetic acid for 10 min (Bryant \& Bloom. 1982). The extracts were stored at $-20^{\circ} \mathrm{C}$ until the assay.

\section{Radioimmunoassays (RIA)}

The RIA for $7 \mathrm{~B} 2$ has been described in full elsewhere (Suzuki et al., 1986b). 7B2 antiserum was raised against a synthetic segment of 7B2 (sequence positions 23-39; Cambridge Research Biochem., Cambridge, U.K.). The antibody exhibited $33 \%$ cross-reactivity on a molar basis with authentic porcine 7B2 and no cross-reactivity was observed for rat follicle stimulating hormone (rFSH), rat luteinizing hormone (rLH), beta-endorphin, somatostatin, rat growth hormone (rGH) or substance P (Igcuhi et al., 1984; Suzuki et al., 1986b; Deng et al., 1986). The sensitivity of the assay was $0.3 \mathrm{fmol} /$ assay tube using synthetic 7B2 (23-39) and iodinated 7B2 (23-39) as standard and tracer, respectively. 
The intra-and inter-assay coefficients of variation were 7 and $12 \%$, respectively.

RIAs of rLH and rTSH were performed by double-antibody procedures and using kits generously provided by the National Institute of Diabetes, Digestive and Kidney Disease (NIDDK), Bethesda, MD, USA, and calculated in terms of the standards for LH-RP-2 and TSH-RP-2. The minimal detectable doses of rLH and rTSH were 18 and $25 \mathrm{pg}$, respectively. The intra- and interassay coefficients of variations for these two RIAs were less than 10\% and $15 \%$, respectively. The RIAs were performed according to the methods described in the protocols. All peptides and proteins were iodinated with sodium 125-I using the choloramine T method (Hunter \& Greenwood. 1962) or lactoperoxidase method (Miyachi et al., 1972).

Plasma free thyroxine concentrations were assessed with a commercial RIA kit supplied by Japan Diagnostic Products Co., Tokyo, Japan.

\section{Statistical analysis}

The significance of difference between several groups of data was assessed by one way analysis of variance (ANOVA). A difference was considered significant if the resulting $\mathrm{F}$ value gave a probability of $<0.05$. Differences between pairs of groups were then assessed by Student's unpaired $t$-test.

\section{Results}

\section{The estrous cycles (Fig. 1)}

No significant changes in pituitary or hypothalamic $7 \mathrm{~B} 2$ concentrations were observed during the cycle. Plasma rLH concentrations were also determined. No significant difference was observed during the estrus cycle (proestrus, $0.48 \pm 0.15$ (mean $\pm \mathrm{SEM}) \mathrm{ng} / \mathrm{ml}$; estrus, $0.20 \pm 0.06 \mathrm{ng} / \mathrm{ml}$; metestrus, $0.54 \pm 0.13 \mathrm{ng} / \mathrm{ml}$; diestrus, 0.21 $\pm 0.05 \mathrm{ng} / \mathrm{ml}$ ).

\section{Endocrinological treatments}

Tissue 7B2 concentrations under the endocrinological treatments are shown in Fig. 2 and Table 1 and 2.

\section{Hyperthyroid and hypothyroid rats}

Plasma free thyroxine concentrations were $11.3 \pm 1.4$ (hyperthyroid rats) and $0.6 \pm 0.2$ (hypothyroid rats) $\mathrm{ng} / 100 \mathrm{ml}$, respectively, and these values were significantly different from the control value $(1.9 \pm 0.2 \mathrm{ng} / 100 \mathrm{ml}$; both $\mathrm{p}<0.01$ ). In hypothyroid rats, plasma

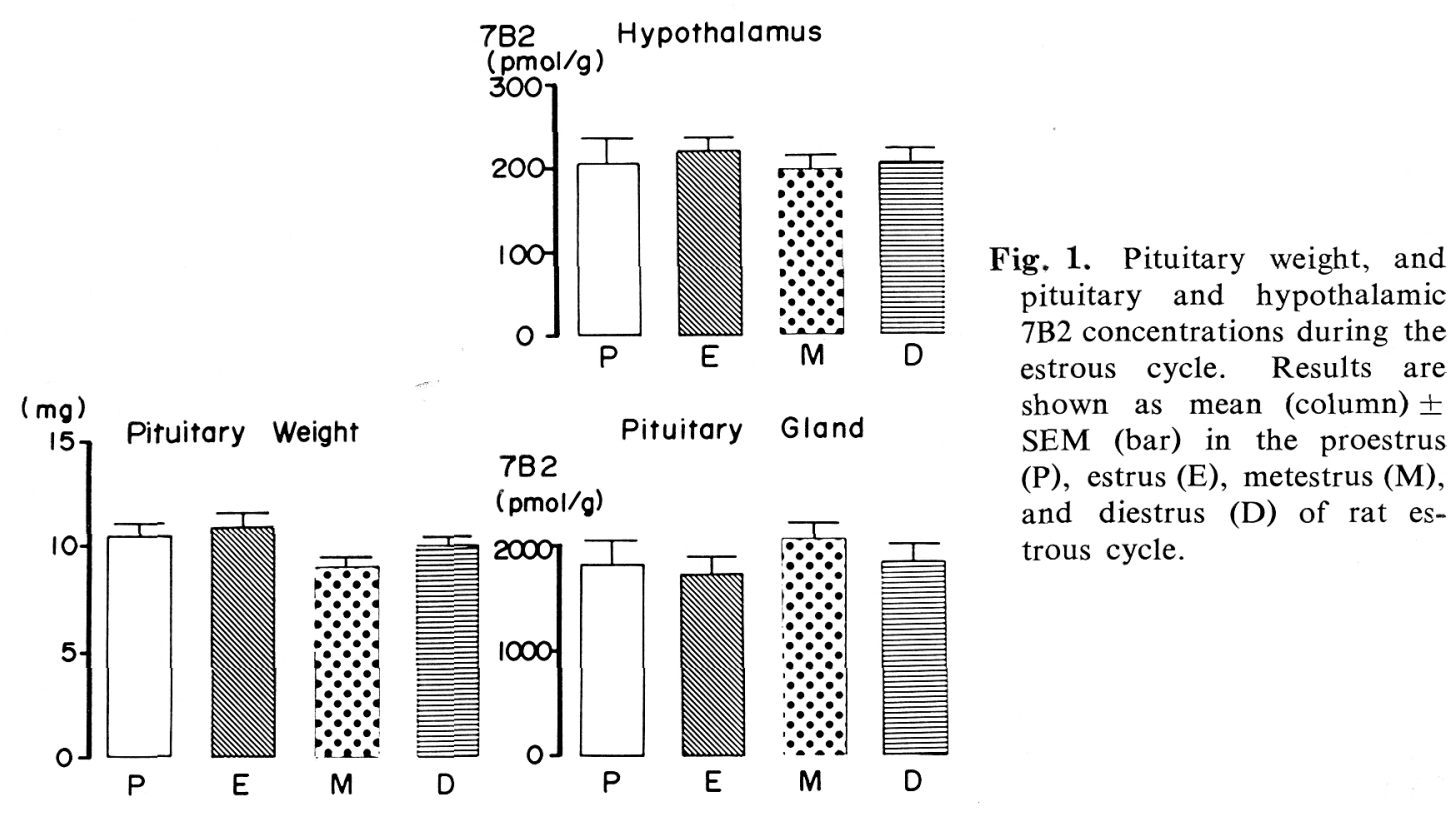




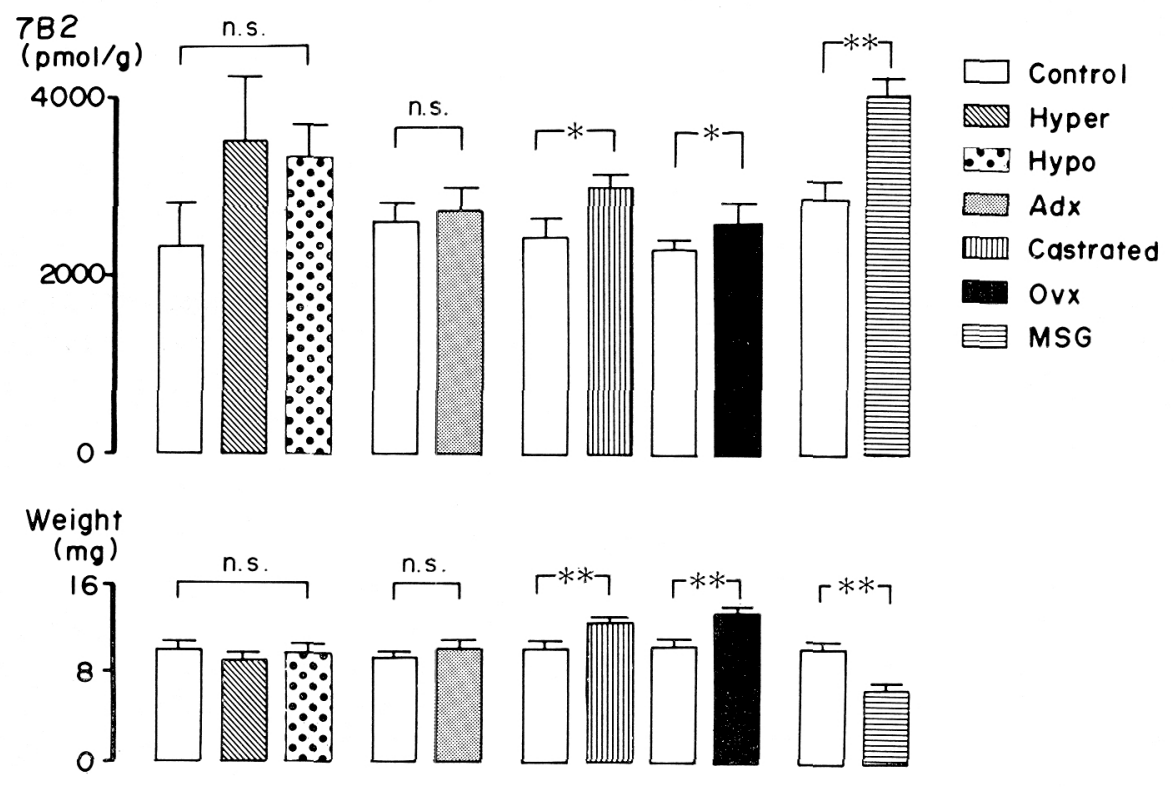

Fig. 2. Pituitary weight and 7B2 concentration in rats subjected to various endocrinological treatments. Abbreviations used in the figure are as follows; ${ }^{*}: \mathrm{p}<0.05 ; *^{*}: \mathrm{p}<0.01$ vs corresponding control value for each; Hyper: hyperthyroid rats treated with thyroxine; Hypo: hypothyroid rats treated with methyl mercaptoimidazole; Adx: adrenalectomized rats ; Castrated: castrated rats ; Ovx : ovariectomized rats; MSG : rats treated with monosodium glutamate neonatally.

Table 1. The effect of various endocrine treatments on 7B2 concentration in the rat brain.

\begin{tabular}{lccccccc}
\hline \hline & Cerebellum & Brainstem & Midbrain & Thalamus & Hypothalamus & Striatum & Cortex \\
\hline T4 (7) & $27.0 \pm 6.9^{*}$ & $36.3 \pm 7.1$ & $152.1 \pm 11.1^{*}$ & $115.9 \pm 16.7$ & $193.0 \pm 26.1$ & $92.1 \pm 15.5$ & $82.4 \pm 10.1^{*}$ \\
MMI (9) & $14.2 \pm 2.6$ & $30.1 \pm 6.4$ & $116.8 \pm 28.7$ & $82.5 \pm 13.8$ & $267.8 \pm 40.6$ & $95.5 \pm 27.6$ & $62.3 \pm 4.5$ \\
Control (6) & $15.6 \pm 2.4$ & $25.7 \pm 3.5$ & $83.3 \pm 9.3$ & $63.7 \pm 9.7$ & $253.0 \pm 31.4$ & $76.4 \pm 13.5$ & $55.5 \pm 12.0$ \\
\hline Adx (12) & $12.8 \pm 2.4$ & $21.7 \pm 4.6$ & $129.7 \pm 24.7$ & $92.7 \pm 13.3$ & $206.8 \pm 19.7$ & $83.4 \pm 10.5$ & $68.6 \pm 6.1$ \\
Contro1 (7) & $17.6 \pm 3.9$ & $24.7 \pm 3.0$ & $95.8 \pm 9.3$ & $70.8 \pm 8.0$ & $239.4 \pm 21.3$ & $80.4 \pm 11.9$ & $48.6 \pm 8.3$ \\
\hline Castrated(11) & $16.7 \pm 2.3$ & $17.2 \pm 3.0$ & $94.6 \pm 8.7$ & $57.9 \pm 10.8$ & $252.6 \pm 14.1$ & $88.2 \pm 10.3$ & $62.0 \pm 8.4$ \\
Contro1 (7) & $19.5 \pm 3.2$ & $25.0 \pm 4.1$ & $97.2 \pm 6.7$ & $76.5 \pm 8.0$ & $242.3 \pm 21.4$ & $91.5 \pm 10.9$ & $46.7 \pm 6.4$ \\
\hline Ovx (8) & $16.4 \pm 2.8$ & $23.9 \pm 6.9$ & $106.4 \pm 18.6$ & $68.5 \pm 6.6$ & $225.5 \pm 15.4$ & $78.2 \pm 11.3$ & $36.8 \pm 7.7$ \\
Contro1 (7) & $16.3 \pm 2.9$ & $27.0 \pm 4.0$ & $112.5 \pm 17.1$ & $73.8 \pm 9.8$ & $248.7 \pm 15.2$ & $109.2 \pm 18.4$ & $44.9 \pm 5.3$ \\
\hline MSG (11) & $21.5 \pm 2.1$ & $31.1 \pm 4.2$ & $195.4 \pm 16.5 * *$ & $117.4 \pm 19.3$ & $354.5 \pm 11.2 * *$ & $116.3 \pm 11.8$ & $51.9 \pm 7.4$ \\
Contro1 (8) & $22.8 \pm 4.6$ & $32.2 \pm 6.8$ & $117.6 \pm 10.7$ & $85.3 \pm 15.8$ & $246.7 \pm 22.6$ & $109.9 \pm 8.5$ & $52.4 \pm 7.6$
\end{tabular}

Results shown are mean \pm SEM and expressed as pmol/g wet weight of the tissue. Numbers in parentheses indicate the numbers of rats studied. Abbreviations used in the Table are as follows; T4: thyroxine-treatment; MMI : methyl mercaptoimidazole-treatment; Adx : adrenalectomy ; Ovx; ovariectomy; MSG: neonatal monosodium glutamate-treatment (for details, see Matelials and Methods).

*, $\mathrm{p}<0.05$ vs corresponding control value.

$* *, \mathrm{p}<0.01$ vs corresponding control value. 
Table 2. 7B2 concentrations in pancreas and gastrointestinal tissues in rats with various endocrine treatments.

\begin{tabular}{lrcccc}
\hline \hline & Stomach & Duodenum & Ileum & Colon & Pancreas \\
\hline T4 (7) & $6.7 \pm 1.3$ & $6.8 \pm 1.2$ & $7.6 \pm 1.5$ & $4.4 \pm 0.5$ & $13.1 \pm 2.2$ \\
MMI (9) & $6.4 \pm 1.2$ & $7.9 \pm 1.4$ & $8.0 \pm 1.4$ & $5.2 \pm 2.5$ & $20.4 \pm 5.7$ \\
Contro1 (6) & $6.1 \pm 1.1$ & $7.2 \pm 1.0$ & $5.8 \pm 1.0$ & $7.3 \pm 1.3$ & $12.8 \pm 2.1$ \\
\hline Adx (12) & $7.9 \pm 1.7$ & $5.3 \pm 0.9$ & $4.7 \pm 1.0$ & $5.4 \pm 1.5$ & $13.2 \pm 3.4$ \\
Control (7) & $6.9 \pm 1.0$ & $6.1 \pm 0.5$ & $5.4 \pm 2.2$ & $7.3 \pm 1.7$ & $11.3 \pm 2.4$ \\
\hline Castrated (11) & $6.1 \pm 3.3$ & $7.9 \pm 2.1$ & $4.7 \pm 1.0$ & $5.4 \pm 1.5$ & $15.0 \pm 3.1$ \\
Contro1 (7) & $5.2 \pm 2.2$ & $8.4 \pm 1.2$ & $4.8 \pm 1.2$ & $5.7 \pm 1.3$ & $13.9 \pm 3.0$ \\
\hline Ovx (8) & $7.1 \pm 1.9$ & $7.1 \pm 1.8$ & $6.9 \pm 2.0$ & $6.3 \pm 1.7$ & $11.8 \pm 2.5$ \\
Control (7) & $6.6 \pm 1.2$ & $8.9 \pm 3.0$ & $5.7 \pm 1.2$ & $4.4 \pm 0.9$ & $13.6 \pm 2.7$ \\
\hline MSG (11) & $10.1 \pm 2.8$ & $10.8 \pm 3.7$ & $9.2 \pm 2.1$ & $6.4 \pm 0.8$ & $16.0 \pm 5.4$ \\
Contro1 (8) & $7.3 \pm 2.8$ & $9.3 \pm 2.3$ & $7.5 \pm 3.0$ & $8.4 \pm 2.6$ & $15.1 \pm 3.0$ \\
\hline
\end{tabular}

For details, see Table 1 .

TSH was increased (hypothyroid; $14.45 \pm$ $0.79 \mathrm{ng} / \mathrm{ml}$; control $1.40 \pm 0.52 \mathrm{ng} / \mathrm{ml}, \mathrm{p}<$ 0.01). In hyperthyroid rats plasma TSH was rather depressed $(0.31 \pm 0.15 \mathrm{ng} / \mathrm{ml})$. These results confirmed the success of the manipulation of thyroid hormone. As shown in Fig. 2 and Table 1, although no significant changes in the pituitary and hypothalamic $7 \mathrm{~B} 2$ concentrations were observed, there were significant differences in $7 \mathrm{~B} 2$ concentrations in some brain regions (cerebellum, midbrain, and cortex) in hyperthyroid rats. $7 \mathrm{~B} 2$ concentrations in GI tracts did not change significantly among the groups (Table 2).

\section{Adrenalectomized rats}

No differences between 7B2 concentrations in adrenalectomized animals and controls were observed in the pituitary (Fig. 2). $7 \mathrm{~B} 2$ concentrations in tissues from the brain and GI tract in adrenalectomized rats did not change significantly from the control values (Tables 1 and 2).

\section{Gonadectomized rats}

Plasma LH levels were significantly raised in castrated males and ovariectomized females compared with control values (castrated, $23.3 \pm 6.0$; male control, $0.26 \pm 0.07$; ovariectomized, $19.1 \pm 5.9$; female control $0.33 \pm 0.10 \mathrm{ng} / \mathrm{ml} ; \mathrm{p}<0.01$ for each sex). In gonadectomized rats, the weight of the pituitary glands increased significantly (castrated, $12.6 \pm 0.5$; male control, $10.3 \pm 0.6$; ovariectomized, $13.5 \pm 0.5$; female control, $10.4 \pm 0.7 \mathrm{mg} ; \mathrm{p}<0.01$ for each sex).

The pituitary 7B2 content in castrated and ovariectomized rats differed significantly $(\mathrm{p}<0.05)$ from that in controls (Fig. 2), though no significant differences were observed in brain regions and GI tract (Tables 1 and 2).

\section{Neonatally MSG treated rats}

All MSG treated rats exhibited typical somatic features (obese, short tail and small testes) and the disappearance of the optic nerve (Olney. 1969). The pituitary glands were significantly smaller than those in

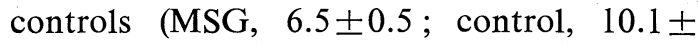
$0.6 \mathrm{mg} ; \mathrm{p}<0.01)$. 7B2 content in the pituitary, hypothalamus and midbrain showed a significant increase $(\mathrm{p}<0.05$ or $\mathrm{p}<$ 0.01 vs control values, Fig. 2 and Table 1).

\section{Discussion}

Immunocytochemical studies revealed that a novel pituitary protein, 7B2, was 
localized in endocrine cells of the rat anterior pituitary cells and particularly localized in gonadotropic cells (Marcinkiewicz et al., 1985, 1986; Steel et al., 1988). In human pituitaries and gonadotropinomas the coexistence of 7B2 and gonadotropin immunoreactivities was observed (Steel et al., 1988). Furthermore, the release of 7B2 from gonadotropes has been demonstrated to be prompted by high potassium and LH-RH (Iguchi et al., 1984; Deng et al., 1986; Natri et al., 1988). These observations were consistent with the possibility that 7B2 is a novel secretory protein and has a close relation to gonadotropes.

On the other hand, Marcinkiewicz et al. (1986) reported that 7B2 immunoreactivity was found to be present not only in gonadotropes but also in thyrotropes. Iguchi et al. (1987) found that there were significant correlations between plasma 7B2 levels in cord blood and the body weight of neonates and plasma growth hormone levels in cord blood. Natri et al. (1988) also demonstrated that plasma 7B2 levels in patients with $\mathrm{GH}$ producing pituitary adenoma were elevated after intravenous GH-RH stimulation and that high potassium induced the release of $7 \mathrm{~B} 2$ from the human somatotrope adenoma cells in vitro.

These complicated results prompted us to study whether any changes could be observed in various endocrine situations. In this study, we failed to find any significant difference in the pituitary 7B2 concentrations during the estrous cycles. A1though it was only of borderline significance, increased 7B2 concentrations were found in castrated and ovariectomized pituitaries. Steel et al. (1988) demonstrated that 7B2 immunoreactivity in ovariectomized pituitaries was more intense, more frequent and more extensive than that in control pituitaries. In contrast to the present study, Deng et al. (1986) observed neither a significant increase in 7B2 content in castrated rat pituitaries nor a significant dif- ference in 7B2 release from castrated rat anterior pituitary cells in vitro. In man, we have demonstrated plasma $7 \mathrm{~B} 2$ release after intravenous LH-RH administration (Kobori. 1989) and high plasma 7B2 in patients with Turner's or Kleinfelter's syndrome (Suzuki et al., in preparation). Because LH and FSH immunoreactive cells have been reported to increase after ovariectomy (Ibrahim et al., 1986) and 7B2 immunoreactivity has been demonstrated to colocalize with gonadotropin immunoreactivities in the pituitary (Marcinkiewicz et al., 1985; Steel et al., 1988), an increase in $7 \mathrm{~B} 2$ content in the pituitary after gonadectomy seemed to be reasonable. The discrepancy in pituitary $7 \mathrm{~B} 2$ content in these gonadectomized rats (Deng et al., 1986; Steel et al., 1988)., might be due to the difference in rate of secretion of pituitary $7 \mathrm{~B} 2$ to the circulation modified by LH-RH or other unknown secretagogues.

In rat pituitaries from adrenalectomized rats and thyroxine or MMI treated rats, no significant change in 7B2 content was found and this result is in accordance with the results of Steel et al. (1988). The significant brain 7B2 increase found in thyroxine treated rats might, however, indicate that thyroid hormones could play a role in $7 \mathrm{~B} 2$ metabolism in the brain.

Paraenteral administration of MSG to neonatal rodents has been reported to result in a central nervous system lesion, restricted largely to neurons of the arcuate nucleus and to the retina (Olney 1969). These rats show typical growth retardation, obesity and atrophy of optic nerve and endocrine glands. It had been reported that anterior pituitary weight and $\mathrm{GH}$ content in the anterior pituitary was reduced (Ieiri et al., 1981). Recently, MSG has been reported to deplete immunoreactive growth hormone releasing factor (GRF) content in pituitary stalk-median eminence tissue (Bloch et al., 1984 ; Wakabayashi et al., 1986). Not only $\mathrm{GH}$ but gonadotropin abnormalities were 
also demonstrated, though results were not uniform due to sex difference (Dada et al., 1984 ; Dada \& Blake 1985 ; Inkster et al., 1985). Furthermore, many other peptides such as adrenocorticotropin. (ACTH), beta endorphin (Krieger et al., 1979), neuropeptide Y (Kererian \& Pelletier 1986) and somatostatin (Depaolo \& Steger 1985), etc. had been shown to be influenced by the treatment. A recent study demonstrated changes in $7 \mathrm{~B} 2$ content in the hypothalamus and substantia nigra (Hashigami. 1989). In the present study, in addition to these observations, a significant increase in pituitary 7B2 content was demonstrated. As Dada et al. (1984) had reported for LH, the calculation of $7 \mathrm{~B} 2$ content on the basis of the entire weight of the pituitaries showed no difference between the MSG treated rats and controls. This result suggest that the increase in $7 \mathrm{~B} 2$ content per mg pituitaries might be of importance in maintaining the normal amount of $7 \mathrm{~B} 2$ in small pituitaries. As the levels of the peptide in the tissue will reflect the balance between release from, synthesis and degradation within the tissue, measurements of tissue content of peptides therefore yield only limited information about the patterns of release. Further studies are obviously needed concerning 7B2 action and the pattern of release from MSG and gonadectomized rats and brain tissues from altered thyroid states.

\section{Acknowledgement}

We acknowledge our gratitude to Professor S. R. Bloom, Royal Postgraduate Medical School, London, for his generous gift of 7B2 antisera. We also wish to thank Dr. A. F. Parlow of the NIDDK for kindly supplying NIDDK immunoreagents.

\section{References}

Bryant, M. G. and S. R. Bloom (1982). Measurement in tissues. In Radioimmunoassay of Gut Regulatory Peptides, S. R. Bloom, R. G. Long (Eds), London, Saunders, pp36-41.

Bloch, B., N. Ling, R. Benoit, W. B. Wehrenberg and R. Guillmin (1984). Specific depletion of immunoreactive growth hormonereleasing factor by monosodium glutamate in rat median eminence. Nature 307, 272-273.

Dada, M. O., J. F. Rodriguez-Sierra, R. W. Clough, L. L. Garner, and C. A. Blake (1984). Monosodium glutamate and pituitary gland luteinizing hormone $(\mathrm{LH})$ release in response to LH-releasing hormone: an in vitro study. Endocrinology 116, 246-251.

Dada, M. O. and C. A. Blake 1985. Monosodium 1-glutamate administration: effects on gonadotropin secretion, gonadotrophs and mammotrophs in prepubertal female rats. $J$. Endocr. 104, 185-192.

Deng, J. Y., J. S. D. Chan, N. G. Seidah, M. Cretien (1986). Specific release of a novel pituitary polypeptide, 7B2, from rat anterior pituitary cells in vitro by luteinizing hormonereleasing hormone. Neuroendocrinology 44, 373-377.

Depaolo, L. V. and R. W. Steger (1985). Alterations in immunoreactive somatostatin levels in hypothalamic and gastro-enteropancreatic tissue as a consequence of neonatal treatment with monosodium glutamate. Proc. Soc. Exp. Biol. Med. 178, 419-425.

Glowinski, J. and L. L. Iversen (1966). Regional studies of catecholamines in the rat brain-(i) the disposition of [3-H]norepinephrine, [3-H]dopamine, and [3-H]dopa in various regions of the brain. J. Neurochem. 13, 655-669.

Hashigami, Y. (1989). Effects of neonatal administration of monosodium glutamate on four neuropeptides concentrations in the rat brain regions. Folia. Endocrinol. Jpn. 65, 79-90 (Japanese with English abstract).

Heffner, T. G., J. A. Hartman and L. S. Seiden (1980). A rapid method for the regional dissection of the rat brain. Pharm. Biochem. Behav. 13, 453-456.

Hsi, K. L., N. G. Seidah, G. De Serres and M. Chretien (1982). Isolation and NH2terminal sequence of a novel porcine pituitary 
polypeptide. Homology to proinsulin, secretin and Rous sarcoma virus transforming protein TVFV60. FEBS Lett 147, 261-266.

Hunter, W. H. and F. C. Greenwood (1962). Preparations of iodine-131 labelled human growth hormone of high specific activity. Nature (Lond.) 194, 495-496.

Ibrahim, S. N., S. M. Moussa and G. V. Childs (1986). Morphometric studies of rat anterior pituitary cells after gonadectomy : correlation of changes in gonadotropes with the serum levels of gonadotropins. Endocrinalogy 119, 629-637.

Ieiri, T., Y. Hashigami, N. Kase, H. Suzuki, T. Nakamura and S-I. Shimoda (1981). Growth hormone synthesis function in adult male rats treated neonatally with monosodium glutamate. Dokkyo J. Med. Sci. 8, 69-73.

Iguchi, H., J. S. D. Chan, N. G. Seidah and M. Chretien (1984). Tissue distribution and molecular forms of a novel pituitary protein in the rat. Neuroendocrinology 39, 453-458.

Iguchi, H., J. S. D. Chan, M. Dennis, N. G. Seidah and M. Chretien (1985). Regional distribution of a novel pituitary protein (7B2) in the rat brain. Brain. Res. 338, 91-96.

Iguchi, H., S. Natri, H. Nawata, K. Kato, H. Ibayashi, J. S. D. Chan, N. G. Seidah and M. Chretien (1987). Elevation of plasma 7B2 (a novel pituitary protein) in cord blood at obstetrical delivery and possible correlation with GH. Life Sci. 41, 1921-1927.

Inkster, S. E., R. N. Clayton and S. A. Whitehead (1985). Pituitary receptors for LHreleasing hormone (LHRH) and responsiveness to LHRH in adult female rats after neonatal monosodium 1-glutamate treatment. J. Endocr. 107, 9-13.

Kererian, L. and G. Pelletier (1986). Effects of monosodium 1-glutamate administration on neuropeptide $\mathrm{Y}$-containing neurons in the rat hypothalamus. Brain. Res. 369, 388-390.

Kobori, H. (1989). Immunoreactive 7B2 concentrations in plasma and cerebrospinal fluid in pathophysiological conditions and the responses to oral glucose load, intravenous LH-RH, TRH and arginine infusion. Folia Endocrinol Jpn. (in press) (Japanese with English abstract).

Krieger, D. T., A. S. Liotta, G. Nicholsen and J. S. Kizer (1979). Brain ACTH and endorphin reduced in rats with monosodium glutamate-induced arcuate nucleus lesions. Nature
278, 562-563.

Marcinkiewicz, M., S. Benjannet, N. G. Seidah, M. Cantin and M. Chretien (1985). Immunocytochemical localization of a novel pituitary protein (7B2) within the rat brain and hypophysis. J. Histochem. Cytochem. 12, 12191226.

Marcinkiewicz, M., N. G. Seidah, S. Benjannet, M. Cantin and M. Chretien (1986). The pituitary peptide "7B2" is associated with LH/FSH and TSH cells and is also found in the CNS and in the peripheral neuroendocrine system: an immunocytochemical study. $J$. Histochem. Cytochem. 34, 1354.

Miyachi, Y., J. L. Vaitukaitis, E. Nieschlag and M. B. Liprett (1972). Enzymatic radioiodination of gonadotropins. J. Clin. Endocrinol. Metab. 34, 23-28.

Natri, S., H. Iguchi, H. Nawata, K. Kato, H. Ibayashi, H. Nakagaki and M. Chretien (1988). Evidence for the release of a novel pituitary polypeptide (7B2) from the growth hormone-producing pituitary adenoma of patients with acromegaly. J. Clin. Endocrinol. Metab. 66, 430-437.

Olney, J. W. (1969). Brain lesions, obesity, and other disturbances in mice treated with monosodium glutamate. Science 164, 719-721.

Schwartz, N. B. and D. Bartosik (1962). Changes in pituitary $\mathrm{LH}$ content during the rat estrous cycle. Endocrinology 71, 756-762.

Seidah, N. G., K. L. Hsi, G. De Serres, J. Rochemont, J. Hamelin, T. Antakly, M. Cantin and M. Chretien (1983). Isolation and $\mathrm{NH} 2$-terminal sequence of a highly conserved human and porcine pituitary protein belonging to a new superfamily. Immunocytochemical localization in pars distalis and pars nervosa of the pituitary and in the supraoptic nucleus of the hypothalamus. Arch. Biochem. Biophys. 225, 525-534.

Steel, J. H., S. Van Noorden, J. Ballesta, S. J. Gibson, M. A. Ghatei, J. Burrin, U. Leonhardt, J. Domin, S. R. Bloom and J. M. Polak (1988). Localization of 7B2, neuromedin $B$, and neuromedin $U$ in specific cell types of rat, mouse, and human pituitary, in rat hypothalamus, and in 30 human pituitary and extrapituitary tumours. Endocrinology 122, 270-282.

Suzuki, H., N. D. Christofides, P. Anand, M. Chretien, N. G. Seidah, J. M. Polak and S. R. Bloom (1985). Regional distribution of a 
novel pituitary protein (7B2) in the rat spinal cord: effect of neonatal capsaicin treatment and thoracic cord transection. Neurosci. Lett. 55, 151-156.

Suzuki, H., A. S. Tischler, N. D. Christofides, M. Chretien, J. M. Polak and S. R. Bloom 1986 a). A novel pituitary protein (7B2)-like immunoreactivity is secreted by a rat phaeochromocytoma cell line (PC 12). J. Endocr. 108, 151-155.

Suzuki, H., M. A. Ghatei, S. J. Williams, L. O. Uttenthal, P. Facer, A. E. Bishop, J. M. Polak and S. R. Bloom (1986 b). Production of pituitary protein 7B2 immunoreactivity by endocrine tumors and its possible diagnostic value. J. Clin. Endocrinol. Metab. 63, 758765.

Suzuki, H., N. D. Christofides, M. Chretien, N. G. Seidah, J. M. Polak and S. R. Bloom (1987). Developmental changes in immunoreactive content of novel pituitary protein $7 \mathrm{~B} 2$ in human pancreas and its identification in pancreatic tumors. Diabetes 36, 1276-1279.

Wakabayashi, I., H. Hatano, S. Minami, Y. Tonegawa, S. Akira, H. Sugihara and N. C. Ling (1986). Effects of neonatal administration of monosodium glutamate on plasma growth hormone $(\mathrm{GH})$ response to $\mathrm{GH}-$ releasing factor in adult male and female rats. Brain. Res. $372,361-365$. 